\title{
JHS English Teachers' and Students' Perceptions on the Implementation of Authentic Assessment in Pekanbaru
}

\author{
Gustari Prima Diharmis ${ }^{1, *}$ Hamzah $^{1}$ \\ ${ }^{1}$ Universitas Negeri Padang, Padang, West Sumatera - Indonesia \\ *Corresponding author.E-mail: tariprima20@gmail.com
}

\begin{abstract}
This research was conducted in order to 1) find the English teachers' perceptions on the implementation of the authentic assessment, 2) find students' perceptions on their teachers' implementation of the authentic assessment, and 3) see if there is a significant difference between teachers' and students' perceptions on the implementation of the authentic assessment. 122 English teachers and 366 students of 41 schools were involved in this research. Questionnaire is the instrument of the research used to collect the data. It was deployed to the teacher and the students. The data were analyzed to find their response rate category in each indicator of authentic assessment. Then, Mann-Whitney test was also used to see whether there is a significant difference between the teacher and the students' perception. The results of the analyses revealed that English teachers' perception on the implementation of authentic assessment is, in average, classified into good category. The students, in general, perceived that their teachers' authentic assessment implementation is categorized into good level. Despite of this result, there is statistically significant difference between the teachers' and the students' perceptions on the implementation of the authentic assessment. These differences are discussed in the present research.
\end{abstract}

\section{Keywords: implementation, authentic assessment, perception}

\section{INTRODUCTION}

Assessment is important in education because the quality of education can be developed through improving the quality of teaching and learning as well as improving the quality of assessment system. This means that a good teaching and learning system will result in good learning quality. Learning quality can be viewed from the result of assessment. A good assessment system will encourage an educator or a teacher to choose a good learning strategy and motivate learners to learn better [1]. Therefore, improving assessment system needs to be applied to improve the quality of education

At least there are three main reasons for the importance of assessment in education. First, teachers and lecturers Law Number 14, 2005 includes giving assessment to learners as one of seven main duties of a professional teacher including giving education, teaching, guidance, direction, training, assessment and evaluation. Second, assessment is one of the contextual teaching and learning (CTL) components that a teacher should do in the teaching learning process. Other components of CTL approach are constructivism, inquiry, questioning, learning community, modeling, and reflection. Finally based on the blueprint Teacher Profession Education Student Competence Exam (UKMPPG), especially in the pedagogic competence teachers should have the ability to design assessment, to assess and to evaluate teaching and learning [2]. In addition to assessment, Regulation of Education and Culture Ministry (Permendikbud) of Republic of Indonesia Number 104, 2014 states that authentic assessment as the form of assessment which acquires learners to demonstrate their attitudes, use knowledge and skills obtained from teaching and learning in doing the tasks in the real situation. In this regulation, in general, authentic assessment is known as assessment of learning achievement or outcomes.

Authentic assessment has been widely used in English Language Learning. In the School-based Curriculum (KTSP), teachers also applied authentic assessment as one of the ways to assess students' learning achievement however, it was not optimally applied. Hence, in the 2013 Curriculum, the authentic assessment is given more serious concern and focus in which teachers are required to assess their students' learning outcomes or achievement. It is clear that authentic assessment is a significant measurement that is by teachers to determine their students' learning outcomes in the aspects of attitude, knowledge and skill.

Authentic assessment as an evaluation process that involves multiple forms of performance measurements reflecting the students' learning, achievement, motivation, and attitudes on instructionally relevant classroom activities [3]. Based on the Education Minister Issue No. 66,2013 , authentic assessment is defined an assessment 
which is conducted comprehensively in order to assess learning input, learning process and learning output. Moreover, authentic assessment is a complete description of students' performance, growth, and progress [4]. In conclusion, authentic assessment is defined as an assessment process which provides opportunity for students to apply their knowledge and perform their attitude and skills in real-life situation. In the 2013 Curriculum, authentic assessment is used to measure students' attitude, knowledge, and skills. In other words, by using authentic assessment, the teachers can gather information on the students' growth. Authentic assessment does not only provide scoring, but also the detail descriptions of what the students have achieved during the learning process. In addition, the teachers can also evaluate their own teaching from their students' learning outcome because the quality of the students is closely related to the quality of the teachers.

Based on the literature review, there were three previous similar topics of research conducted by others, firstly, the result of the research conducted by Aliningsih and Safwan [5] showed that the English teachers had positive perception towards authentic assessment, however, they had insufficient time, crowded classes, exhausting and time consuming, and complicated administration. Secondly, the result of the research carried out by Hayati, Bentri and Rahmi [6] indicated that implementing authentic assessment was exhausting and tiring since teachers required to design their own assessments to determine their students' scores and grades, and learning progress report. The results of the research also revealed that most of the teachers did not do affective and psychomotor aspects optimally. Thirdly, based on the research conducted by Amiza [7] it was found that $40 \%$ of teachers are in the poor category in implementing the types of assessment.

This research limits its discussion to JHS English teachers' and students' perceptions on the implementation of the authentic assessment as shown in the title of the article.

There are three purposes of conducting the research as presented as follows:

1. to find the perceptions on the implementation of the authentic assessment of the 2013 curriculum by JHS English Teachers.

2. to find the perceptions by students on their teachers' implementation of the authentic assessment of the 2013 curriculum.

3. to find if there is a significant difference between teachers' and students' perceptions on the implementation of the authentic assessment of the 2013 Curriculum.

The findings of this research are expected to give some beneficial contributions theoretically and practically. Theoretically, this research can be used especially by English teachers as a reference on the implementation of the authentic assessment of the 2013 Curriculum in the Public Junior High Schools. Practically, the result of this research can give contributions to the teachers as a guideline to implement the authentic assessment in a better way to improve the students' learning achievements and the teaching quality.

\section{METHODOLOGY}

This is a survey approach design research involving 122 English teachers (out of 154 teachers as population) and 366 students (out of 4840 students as population) from 41 Public Junior High Schools (JHS) in Pekanbaru, Riau. Questionnaires as the main instrument for teachers and students are used to collect the data needed in this research. This instrument is used to investigate the teachers' and students' perceptions on the implementation of authentic assessment, and it is also used to seek whether there is a significant difference between teachers' and students' perceptions towards it. The samples (teachers and students) were chosen randomly from the schools.

Prior to distributing the questionnaires to the subjects of the research, questionnaires for teachers and students should have been, at the very first, validated by experts to check the content as well as language use. This is very important to avoid misunderstanding and misinterpretation about the items of the questionnaires

In data collection, the researcher asked the principals or the vice principals of the curriculum affairs of the schools for granting permission to collect the research data. The researcher asked for the help of the principals or vice principals to choose teachers and students to become the subjects of the research. The researcher also mentioned that the names of the teachers and students as well as the names of the schools would not be stated in the final report or in this thesis except by giving their initials and school numbers. The data obtained were analyzed by using descriptive statistics technique to find out the response rate category of the participant. In addition, Mann whitney test was also used to see the difference between the teachers and the students' perception of authentic assessment.

\section{RESULTS AND DISCUSSIONS}

RESULTS

Table 1: Summary of JHS English Teachers' and

Students' Perceptions on the Implementation Authentic Assessment

\begin{tabular}{clcc}
\hline \multicolumn{2}{c}{$\begin{array}{c}\text { Indicators of Authentic } \\
\text { Assessment }\end{array}$} & \multicolumn{2}{c}{ Respondent } \\
\cline { 2 - 4 } Planning & $\begin{array}{l}\text { Mean } \\
\text { score }\end{array}$ & 4.30 & - \\
\cline { 2 - 4 } & $\begin{array}{l}\text { Response } \\
\text { rate } \\
\text { category }\end{array}$ & Good & - \\
\hline & $\begin{array}{l}\text { Mean } \\
\text { score }\end{array}$ & 4.22 & 4.40 \\
\cline { 2 - 4 } $\begin{array}{c}\text { Implementation } \\
\text { information }\end{array}$ & $\begin{array}{l}\text { Response } \\
\text { rate } \\
\text { category }\end{array}$ & Good & Good \\
\hline Affective & $\begin{array}{l}\text { Mean } \\
\text { score }\end{array}$ & 3.93 & 4.17 \\
\hline
\end{tabular}




\begin{tabular}{clcc}
\hline & $\begin{array}{l}\text { Response } \\
\text { rate } \\
\text { category }\end{array}$ & Enough & Good \\
\hline \multirow{2}{*}{ Cognitive } & $\begin{array}{l}\text { Mean } \\
\text { score }\end{array}$ & 4.22 & 4.41 \\
\cline { 2 - 3 } & $\begin{array}{l}\text { Response } \\
\text { rate } \\
\text { category }\end{array}$ & Good & Good \\
\hline \multirow{3}{*}{ Performance } & $\begin{array}{l}\text { Mean } \\
\text { score }\end{array}$ & 3.69 & 4.15 \\
\cline { 2 - 4 } & $\begin{array}{l}\text { Response } \\
\text { rate } \\
\text { category }\end{array}$ & Enough & Good \\
\hline
\end{tabular}

Table 1 above serves the comparison between English teachers' and students' perceptions on the implementation of the assessment (from mean score and response rate perspective). From this table above, the teachers' perceptions on the authentic assessment are categorized into good, good, enough, good, and enough respectively. On the other hand, students' perception for the whole indicators can be categorized into good level. Thus, there are two differences found between teachers' and students' perceptions of the implementation of authentic assessment. The differences can be spotted in indicator affective and performance whereas teachers got enough level for both indicators and students got good level. This finding indicates that there are differences between teachers' implementation and students' perception about authentic assessment. Hence, to find out if these differences are significant statistically, MannWhitney Test was conducted through the following steps.

Mann-Whitney test is used to find the difference between the two independent groups. With the help of SPSS software, it can be seen the result of the analysis as the following table.

Table 2: Mean Rank of Teachers' and Students' Perception of Authentic Assessment

\begin{tabular}{ccccc}
\hline & Respondent & $\mathrm{N}$ & $\begin{array}{c}\text { Mean } \\
\text { Rank }\end{array}$ & $\begin{array}{c}\text { Sum of } \\
\text { Ranks }\end{array}$ \\
\hline Authentic & Teacher & 122 & $\mathbf{1 7 5 . 9 1}$ & 21460.50 \\
\cline { 2 - 5 } Assessment & Student & 366 & $\mathbf{2 6 7 . 3 6}$ & 97855.50 \\
\cline { 2 - 5 } & Total & 488 & & \\
\cline { 2 - 5 } & & & & \\
\hline
\end{tabular}

Table 2 above displays that the mean rank for teachers is 175.91 and the mean rank for students is 267.36. in other words, the teachers' mean rank is less than the mean rank of the students. To find if this difference in mean is significant statistically, it can be seen from the following table.
Table 3: The Result of Mann-Whitney U Analysis

\begin{tabular}{lc}
\hline & Authentic Assessment \\
\hline Mann-Whitney U & 13957.500 \\
\hline Wilcoxon W & $\mathbf{2 1 4 6 0 . 5 0 0}$ \\
\hline$Z$ & $\mathbf{- 6 . 2 0 7}$ \\
\hline Asymp. Sig. (2-tailed) & .000 \\
\hline
\end{tabular}

Based on table 3 above, the value of $U$ is 13957.5 , the value of $\mathrm{W}$ is 21460.5 . When this value is converted into $\mathrm{Z}$, it becomes -6.207 . Based on the table, it can also be seen that the value of sig. is 0.000 . It is less than the value of sig. Alpha at 0.05. If the value of sig. is less than the value of sig. Alpha at 0.05 , Alternative hypothesis $\left(\mathrm{H}_{\mathrm{a}}\right)$ is accepted. Thus, it can be concluded that there is a significant difference between the two groups. In other words, there is a significance difference between teachers' implementation of authentic assessment and students' perception toward it.

\section{DISCUSSIONS}

1) The Implementation of Authentic Assessment by English Teacher of the State Junior High Schools in Pekanbaru

The statistical analysis in the previous section reveals that the JHS English teachers' perceptions on the implementation of authentic assessment in Pekanbaru is categorized into good level. It implies that they have implemented a good plan in authentic assessment, given the implementation information to the students, and really measured students' cognitive aspect by using authentic assessment technique. This result is in line with the study conducted by Fitriani [8] who found that the English teachers have implemented authentic assessment based on 2013 Curriculum directions despite of some obstacles. In addition, a study conducted by Rizavega [9] also showed the same result with the present study. In her study, it is concluded that EFL teachers' ability in implementing authentic assessment is satisfactory with $75 \%$ successfulness rate. This good level of authentic assessment implementation is due to many factors, including teachers' positive perception (which also includes their belief, knowledge, attitude, and feeling) toward authentic assessment. Based on Imansyah et. al. [10], EFL teachers have positive perception toward authentic assessment. This positive perception is clearly helpful for them to carry out this kind of assessment as part of 2013 Curriculum.

Despite the good category, the result of this study also reveals that the teachers' response rate in two indicators of the authentic assessment (affective and performance indicators) is categorized into enough. Based on their answers to the questionnaire, the teachers admitted that they planned to assess their students' performance skills but only sometimes or rarely asked and put their students into the situation dealing with performance skills 
such as conducting a speech, interviews, retelling, role play and etc. This is clearly contradictory to the one of the characteristics of authentic assessment that is it requires the students to perform, create, produce, or do something.

There are many reasons why performance skill activities mentioned above are not conducted and scheduled by the teachers in the context of this study. It needs more than a questionnaire to find them out. However, the hypothesis lies on the time management of the teachers. Rizavega [9] argues that time management is the biggest problem for the teachers to conduct authentic assessment. In different place, Mardjuki [11] finds that assessing students' speaking and writing skills is time consuming and it becomes one of the barriers in authentic assessment application. Accordingly, certain indicators (and it has usually been the oral performance skills) are put aside of another. Therefore, teachers' category in affective and performance indicators of authentic assessment is at enough level.

\section{2) The Students' Perception about the Implementation of Authentic Assessment by Their Teachers}

The data analysis in the previous study has revealed that the JHS students in Pekanbaru have a positive perception towards their teachers' implementation of authentic assessment. It is indicated by the mean value of their response rate which is categorized into good level in all indicators of authentic assessment. This result is quite different from the result of their teachers' implementation of authentic assessment whereas two indicators are at enough category.

As per indicator, it can be seen that, students have good perceptions toward the implementation information of the authentic assessment given by their teachers. In certain items such as item 1, 2, and 6, most of the students completely agreed that their teachers informed them about cognitive and affective competence that would be assessed. According to Fox et. al. [12], in authentic assessment implementation, communication with the students is important and hence should be taken place. Thus, the students will understand what and how the assessment will be addressed to them so that they will not only drive the given task but also contribute to the task meaningfully. In the context of this study, since the teachers are found to understand the importance of implementation information indicators, their students can recognize it very well which means at this stage, the authentic assessment component has run accordingly. The same thing is also prevailing with other indicator namely cognitive aspect.

\section{3) The Teachers' and the Students' Perceptions on the Implementation of Authentic Assessment}

In general, the teachers' and students' perceptions on the implementation of the authentic assessment are categorized into a good level. It means that the implementation of authentic assessment by the teachers has been based on the criteria and direction of the authentic assessment. Likewise, the positive perception of the students towards the implementation of the authentic assessment indicates that students understand the concept of the assessment applied by their teachers.

Yet, the comparison between the mean scores and response rates of teachers' and students' perceptions on the implementation of the authentic assessment on each indicator revealed an interesting sight. The teachers and the students have similarities on two indicators namely implementation information and cognitive indicators. Most of the students completely agreed that their teachers had given implementation information and assessed their cognitive ability. However, they also had differences in other two indicators namely affective and performance indicators. The statistical analysis has proved that these differences are to some extent significant.

There are several suggested reasons why the gap of the teachers and the students on the authentic assessment occured. In affective indicators, for example, the students admitted that their teachers asked them to assess their competence by themselves, the teachers might think that this process depended much on the ability of each student to conduct self-assessment. Almost some students considered themselves not very objective as evaluator in self-assessment so that they needed guidance form the teachers [13]. In different place, Asdar [14] found that there were still some students who did not know what to do when doing self-assessment. This finding indicated that self-assessment would not work very well with low ability students and therefore sometimes the teachers did not perform this very often or did not depend on this very much. The same thing also took place when asking the students to tell the students' accurate group work since it is hard for them to assess a so-called accurate group work if there were no precise criteria and teachers' guidance.

In performance skill indicators, the difference between students and the teachers might occur due to obstacles in implementing the authentic assessment. Among the obstacles are the problems which threat the teachers when assessing certain communicative functions and the availability of the practical instrument to assess performance tasks conducted by the students. According to Zaim et. al [15]teachers still had problems in authentically assessing communicative functions of speaking skills (describing place, describing people, and etc.), and assessment forms (role play, debates, speech, act out etc.) were due to lack of simple and practical instrument for the teachers to use. Therefore, it forces the teachers to only partially implemented aspects on performance skill indicator.

It is true that sometimes the teachers may ask the students to perform, present, to do role play and etc. However, it will be difficult for most of them to deal with the problems mentioned above. As a result, an application of the performance task is functioned in the classroom only to fulfill the prerequisite of the 2013 Curriculum without a precise goal of it. However, based on the students' perception, they still perceive that the teachers 
have given and asked them to do those performance tasks. That is the possible reason that stimulates the difference.

\section{CONCLUSIONS}

This research discusses the JHS English teachers' and students' perceptions on the implementation of authentic assessment of 2013 Curriculum in Pekanbaru. From the data analysis and its discussion, it can be concluded as follows:

Firstly, based on teachers' perceptions, the implementation of the authentic assessment by the JHS English teachers in Pekanbaru in general is categorized into good level. This can be seen from the mean score and the response rates of the questionnaire. However, for each indicator of the authentic assessment, there are two indicators in which the level of teachers' response rates is categorized into enough levels especially affective and performance indicators. This is due to the obstacles that the teachers usually faced during the implementation of authentic assessment so that they cannot make it better at these two indicators.

Then, the students' perceptions towards the implementation of the authentic assessment by their teachers is categorized into good level. The result is lightly different from their teachers, because the students' responses rate is at a good level in every indicator of authentic assessment.

Finally, the comparison between the implementation of authentic assessment by the teachers and students' perceptions toward it indicate that there is $a$ significant difference between these two variables. Therefore, alternative hypothesis is accepted. It means that the implementation of authentic assessment by the teachers is perceived differently by their students due to some factors including problems found during authentic assessment implementation.

\section{REFERENCES}

[1] Mardapi, Djemari. 2008. Teknik Penyusunan Instrumen Tes dan Nontes. Jogjakarta: Mitra Cedikia Offset.

[2] Direktorat Jenderal Pembelajaran dan Kemahasiswaan Kementrian Riset, Teknologi dan Pendidikan. 2017. Buku Panduan UKMPPG: Panduan Umum UKMPPG. Jakarta: Direktorat Jenderal Pembelajaran dan Kemahasiswaan Kementrian Riset, Teknologi dan Pendidikan.

[3] O'Malley, J.M., and L. V. Pierce. 1996. Authentic Assessment for English Language Learners. Menlo Park: Addison-Wesley Publishing Company, Inc.
[4] Van Wyk, L. M., and A. E. Carl. 2010. The Portfolio as an Authentic Assessment Tool for Learning: Is it Serving its Purpose? Stellenbosch: Stellenbosch University.

[5] Aliningsih, Fitri. 2015. English Teachers' Perception and Practices of Authentic Assessment. Retrived from http://journal.unnes.ac.id on March $1^{\text {st }}, 2019$.

[6] Hayati, Abna, A. Bentri, and U. Rahmi. 2017. Analyzing the Issues in the Implementation of Authentic Assessment in the 2013 Curriculum. AlTa'lim Journal, 24(1), 53-59.

[7] Amiza, Elsi. 2019. The Implementation of Authentic Assessment by English Teachers Using the 2013 English Curriculum at SMA 1 Padang Panjang. Menara Ilmu LPPM UMSB Vol. XIII No. 3, 43-56.

[8] Fitriani. 2017. Implementing Authentic Assessment of Curriculum 2013: Teachers' Problem and Solutions. Getsempena English Education Journal (GEEJ) 4(2). 164-171.

[9] Rizavega, Inggrid Hana. 2018. Authentic Assessment Based on Curriculum 2013 Carried by EFL Teacher. Journal Profesi Keguruan (JPK) 4(2). 142-149.

[10] Imansyah, et. al. (2018). "An Analysis of the EFLTeacher Perception about Authentic Assessment". Voices of English Language Education Society (VELES) 2(2). 98-104.

[11] Mardjuki, Moch. Said. 2018. English Teachers Perception on the Use of Authentic Assessment in 2013 Curriculum. Indonesian Journal of English Language Teaching and Applied Linguistics 2(2). 151-163.

[12] Fox, James, et. al. 2017. Keeping It Real: A Review of the Benefits, Challenges, and Steps toward Implementing Authentic Assessment. All Ireland Journal of Teaching and Learning in Higher Education (AISHE-J) 9(3). 3232-3239.

[13] Munoz, Ana and Alvarez, Martha, E. 2007. Students' Objectivity and Perception of Self Assessment in an EFL Classroom. The Journal of ASIA TEFL 4(2). 1-25.

[14] Asdar, Asdar. 2017. Students' Self-Assessment on Their Spoken Interaciton Using CEFR. The 1st Education and Language International Conference Proceedings Center for International Language Develeopment of Unissula. 141-161.

[15] Zaim, M. et. al. 2020. Authentic Assessment for Speaking Skills: Problems and Solution for English Secondary School Teachers in Indonesia. International Journal of Instruction 13(3). 587-604 